\title{
Environmental Friendly Dyeing of Silk Fabric with Natural Dye Extracted from Cassia singueana Plant
}

Taame Berhanu Teklemedhin* and L. Hari Gopalakrishnan

Department of Textile Engineering, Dire Dawa Institute of Technology, Dire Dawa Univerity, Dire Dawa, Ethiopia

\begin{abstract}
Introduction and application of eco-friendly natural dyes on textile coloration have significant importance on the reduction of environmental pollution. Due to this reason many scientists are doing research work on natural dye application on textile materials in the past few years. Having this in mind, this investigation was concerns with the dyeing of silk fabric with colorant extracted from bark of Hambo Hambo (Cassia singueana) plant in the presence of Aloe Vera as natural mordant. Aqueous extraction method was employed for obtaining coloring components. The extraction parameters have been studied and optimum dye extraction condition was examined under UV-Visible spectroscopy which recorded its maximum absorption as $(A=3.9)$. Silk fabric was dyed with the extracted natural dye without mordant and in the presence of synthetic and natural mordants using different mordanting techniques. The color strength, CIE $L^{*} a^{*} b^{*}$ values and fastness properties of the dyed samples were analysed according to the international standards. The Washing fastness, rubbing fastness and light fastness obtained from the directly dyed without mordant and dyed using with Aloe Vera and Copper sulphate $\left(\mathrm{CuSO}_{4} \cdot 5 \mathrm{H}_{2} \mathrm{O}\right)$ mordants was almost similar which was recorded in the range of very good to excellent. The results of this investigation led to the conclusion that there is possibility of dyeing of silk fabric using natural dye extracted from Cassia singueana plant directly without mordant and dying in the presence of Aloe Vera with acceptable range of fastness properties of dyed silk fabric.
\end{abstract}

Keywords: Extraction; Mordents; Natural dye; Cassia singueana plant; Silk; Enviromental friendly dyeing; Aloe vera

\section{Introduction}

The Textile industry is one of the biggest consumers of synthetic dyes [1]. Basically, synthetic dyes are produced from cheap petroleum and coal-tar sources Pervaiz et al. and Devi et al. which are injurious to health, destroying eco-system and toxic to aquatic biodiversity [24]. Due to the current Environmental consciousness, the researcher's attention has been shifted to the use of natural dyes for dyeing textile materials in the past few years $[5,6]$.

Demand of natural dyes is increasing continuously as their production and application does not require strong acids and alkalies $[6,7]$. Natural dyes are believed that, they have better biodegradability, have wide variety non-toxic, non-carcinogenic, easily available and renewable, eco-friend and generally higher compatibility with the environment; provide a wide range of beautiful shades with acceptable levels of color fastness [8-13]. As a result, it is the best alternative using natural colorants in textile application as compared with synthetic dyes [14]. Coloring components can be getting from roots, barks, leaves, fruits and flowers of plant sources. Natural dyes are not only release medicinal properties but also improve the aesthetic value of the product and they are unique and eco-friendly [15]. The extract of this plant were used in northern Nigeria for the treatment of anti-microbial and acute malaria attack [16,17]. The aspect of producing textile products without impacting on the ecological balance, affecting both human and environmental health, is an important focal point to be pursued. Therefore, to address some of these issues this study was aimed to dye silk fabric with eco-friendly natural dye and natural mordant extracted from bark of Cassia singueana plant and Aloe vera respectively.

Cassia singuena plant belongs to the class Leguminosae and family Caesalpinioideae which have an antimicrobial and antiplasmodial activity [17]. It has also composition of Phenols, Saponins, Tannins and anthraquinones and those chemical compositions of tannins and anthraquinones indicates that it can be used as coloring material as shown the structure in Figure 1 [16-18].

Tanned leather materials were dyed using extracted natural dye from Cassia singueana plant in the presence of natural mordants<smiles>Cc1cc2c(c(O)c1-c1c(C)cc3c(c1O)C(=O)c1c(O)cccc1C3=O)C(=O)c1cc(O)cc(O)c1C2=O</smiles>

Figure 1: Typical Chemical structure of Tannins and anthraquinones of Cassia singueana Plant.

obtained from Aloe vera and mango bark resulted Effective results of color fastness and color strength [19]. Aloe Vera juice was also selected as natural mordant to standardize the dyeing effect of Mari gold dye on natural and synthetic fibers which is investigated by Nilani et al. [20]. This Aloe vera was also used as mordant in dyeing of tanned leather materials with natural dye studied by Berhanu and Ratnapandian and also can be used as an antimicrobial finish of textiles as mentioned by the author Athiban et al. [19-21].

In general, the dyeing silk fabric with extracted natural dye from Cassia singuana plant and extracted mordant from Aloe Vera will give the following advantages; 1) since no synthetic dyes or chemicals are added during dyeing it is possible to say this is fully environmental friendly dyeing method, 2) Since the Cassia singuana plant and Aloe vera has property of anti-malarial and anti-microbial activity respectively, this dyed silk fabric will behave anti-malarial and antimicrobial at the same time.

*Corresponding author: Taame Berhanu Teklemedhin, Department of Textile Engineering, Dire Dawa Institute of Technology, Dire Dawa University, Dire Dawa, Ethiopia, Tel: +251-936-425-002; E-mail: taameberhanu2008@gmail.com

Received July 04, 2018; Accepted July 11, 2018; Published July 18, 2018

Citation: Teklemedhin TB, Gopalakrishnan LH (2018) Environmental Friendly Dyeing of Silk Fabric with Natural Dye Extracted from Cassia singueana Plant. J Textile Sci Eng S3: 001. doi:10.4172/2165-8064.S3-001

Copyright: (C) 2018 Teklemedhin TB, et al. This is an open-access article distributed under the terms of the Creative Commons Attribution License, which permits unrestricted use, distribution, and reproduction in any medium, provided the original author and source are credited. 


\section{Materials and Methods}

\section{Materials and chemicals}

The bark of Cassia singueana plant and Fresh leaves of Aloe vera as shown in Figures 1 and 2 were collected manually from Northern Ethiopia (Tigray). Bleaching (degummed) silk fabric was obtained from mark. Formic acid $\left(\mathrm{CH}_{2} \mathrm{O}_{2}\right)$ and Copper sulphate $\left(\mathrm{CuSO}_{4} \cdot 5 \mathrm{H}_{2} \mathrm{O}\right)$ were used to control the $\mathrm{pH}$ of the dye bath and used as synthetic mordant for comparison respectively.

\section{Equipment and testing devices}

Main Equipment and Testing Devices used throughout this work were; Mechanical grinder, Eco-infrared dyeing machine, Oven dryer, $\mathrm{pH}$ meter used to check $\mathrm{pH}$, digital electronic balance was used to measure weight of materials and chemicals, Perkin Elmer UV/VIS Spectrometer was used for measuring color absorption, COLOREYE 3100-was used for measuring reflectance, K/S and CIE $\mathrm{L}^{*} \mathrm{a}^{*} \mathrm{~b}^{*}$ and Fastness (Wash fastness, Light Fastness and Rubbing fastness) testing devices. All those Equipment and Testing Devices were obtained from Bahir Dar University-EiTEX.

\section{Methods}

Dye extraction and optimization: Aqueous extraction method was employed for extraction of coloring components from the bark of Cassia singueana plant. Pervaiz et al. extracted natural dyes from bark of different plants with temperature $\left(90^{\circ} \mathrm{C}\right)$ and time $60 \mathrm{~min}$ [22]. Plant parts were collected and washed thoroughly with water to remove soil and dust particles $[22,23]$. The washed plant materials were shade dried until the moisture is reduced as much as possible. The dried bark was grinded and sieved with 0.5 particle size to obtain the fine powder. The powder was immersed in distilled water with using different combinations of bark concentrations of $(20 \mathrm{~g} / \mathrm{l}, 40 \mathrm{~g} / \mathrm{l}$ and 60 $\mathrm{g} / \mathrm{l})$ for 24 hours. The solution was subjected to temperatures of (45, 75 and $95^{\circ} \mathrm{C}$ ) and time ( $30 \mathrm{~min}, 45 \mathrm{~min}$ and $60 \mathrm{~min}$ ) respectively. The dye solution was filtered and its absorption was tested using UV-visible spectroscopy (Model lambda 25). The temperature, concentration and time at which attain maximum absorption was taken as an optimum condition for extraction of natural dye from Cassia singueana to extract the dye solution from the plant nine experiments were conducted which was decided and calculated by the statistical Minitab software (Figure 2).

Determination of percentage of dye yield: The dye percent of yield was calculated using equation (1)

$$
\text { percent of dye yield }=\frac{\text { mass of plant leaves }- \text { mass of dried precipitate }}{\text { mass of plant leaves }} \times 100
$$

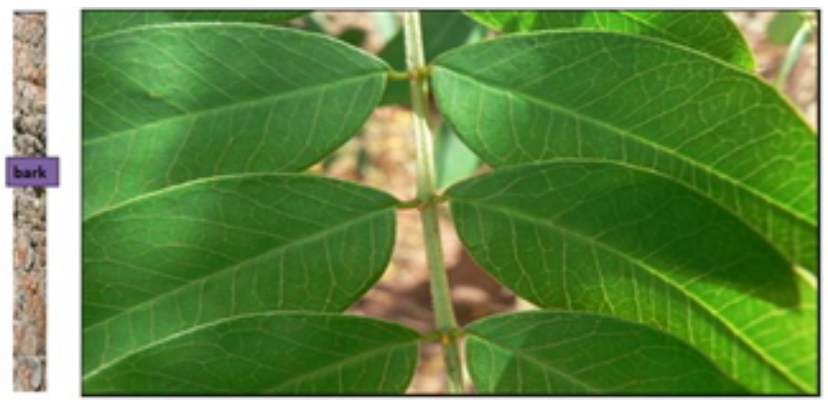

Figure 2: Typical picture of Cssia singueana Plant.
Mordant extraction from Aloe vera leaf: Fresh leaves of Aloe vera was collected and washed thoroughly, the outer green surface was peeled off and the inner white mass was collected and crushed to semi solid form using electronic agitator. The crashed semi solid form of Aloe vera becomes filtered. According to Nilani et al. natural mordant was extracted from Aloe Vera leaf by crashing $150 \mathrm{~g} / \mathrm{l}$ of whit inner part of Aloe vera leaf and heated $50-100^{\circ} \mathrm{C}$ for $1 \mathrm{~h}$ (Figure 3) [20].

Mordanting methods: Natural dyes typically have lower affinities to textiles synthetic dyes. As a result they often required mordants [24]. Three different mordanting techniques (i.e. Pre mordanting, Post Mordant and simultaneous mordanting) were carried out as shown in Figure 3. Silk fabric samples were treated with the extracted natural mordant (Figure 4).

Protein fabrics were dyed with Morus Alba plant bark extract using Aloe Vera as natural mordant and different synthetic mordants which was reviewed by Shoba K et al. [25]. Natural dye with Aloe Vera mordant shows a good dyeing effect and color fastness on the animal fibers. Srivastavaa S, Chopraa A, et al. were extracted natural dye from Rheum emodi and applied on protein fabric which was mordanted with different natural mordants with MLR of 1:20 and temperature of $70-80^{\circ} \mathrm{C}$ for $60 \mathrm{~min}$ [26]. Therefore by taking those literatures as a reference, the mordanting MLR, concentration, temperature and time was selected randomly and designed as shown in Table 1.

Key: CPRM (Pre mordanted with copper sulphate), CPOM (Post mordanted with copper sulphate), SMC (Simultaneously mordanted with copper sulphate), APRM (Pre mordanted with Aloe Vera), APOM (Pre mordanted with Aloe Vera), SMA (Simultaneously mordanted with Aloe Vera), SM (Simultaneously mordanting), POM (Post mordanted), PRM (Pre mordanting).

Dyeing procedure: Natural dyes were extracted from different plants and applied to tanned leather in the presence of mordants and without mordant under identical conditions to find out whether the extracted dye shows affinity to tanned leather in the absence of mordant [11]. Win et al. was also extract natural dye from mango bark and applied on Protein fibers with temperature, time and MLR of 50$80^{\circ} \mathrm{C}, 60 \mathrm{~min}$ and 1:25 respectively [23]. The dyed material gives good color fastness property and attractive color shade. Natural dye was extracted from Odina wodier plant bark and applied on wool fabric with different temperature such as 40,60 and $80^{\circ} \mathrm{C}$ for 1 hour which is done by Saravanan $\mathrm{P}$ et al. [12]. It has been noted that, the K/S value was good at $80^{\circ} \mathrm{C}$.
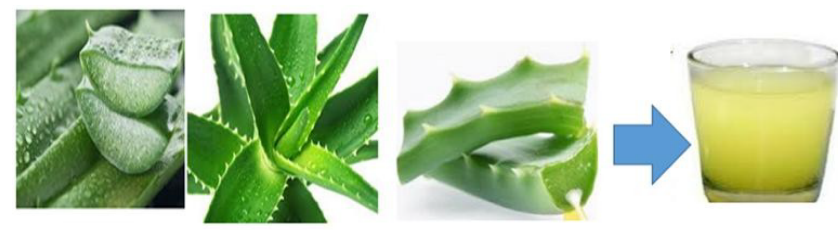

Figure 3: Typical picture of Aloe Vera leaf

\begin{tabular}{|l|l|}
\hline Silk fabric \\
\hline Silk fabric \\
\hline Silk fabric \\
Figure 4: \\
(Mypical mordanting techniques. \\
\hline
\end{tabular}


Citation: Teklemedhin TB, Gopalakrishnan LH (2018) Environmental Friendly Dyeing of Silk Fabric with Natural Dye Extracted from Cassia singueana Plant. J Textile Sci Eng S3: 001. doi:10.4172/2165-8064.S3-001

Sangeetha $\mathrm{K}$ et al. extracted natural dye from lemon leaves and applied on Silk fabric using different natural mordants with MLR (1:20), Temperature $\left(60-90^{\circ} \mathrm{C}\right)$ and time for dyeing and mordanting $(30$ and $60 \mathrm{~min}$ ) respectively [27]. Therefore, similar condition were employed for dyeing of silk fabric using an extract of bark of Cassia singueana plant and natural mordant with dyeing temperature of $25,40,55$ and $70^{\circ} \mathrm{C}$, time of $20,30,45$ and $60 \mathrm{~min}$ and $\mathrm{pH}$ of 5.5, 5, 4.5, 4 and 3.5 were randomly selected as shown in Table 2 . Level of $\mathrm{pH}$ for the extracted dye and silk fabric was cheeked by using $\mathrm{pH}$ meter. The temperature, $\mathrm{pH}$ and time at which the dyed silk fabric attained highest K/S value were selected as optimum dyeing condition. Four experiments were selected through random selection method and conducted under each dyeing and mordanting methods as shown in Table 2 . The weight of each specimen which was dyed with the extracted dye was 30 grams. All necessary calculations was carried out based on the weight of the sample and decided MLR (Table 2).
Evaluation of dyed silk fabric sample: Color fastness (Wash fastness, rubbing fastness light fastness) properties of the dyed silk fabric samples were determined under the optimized conditions according to ISO 105-CO3, ISO 105-X 12 methods and ISO $105 \mathrm{~B} 02$ method respectively.

\section{Results and Discussion}

\section{Optimization of natural dye extraction from Cassia singueana plant}

Natural dye solution was extracted from the bark of Cassia singueana plant at different bark powder concentration, temperature and time. The absorption of resultant solution was determined using UV-Visible spectroscopy (Lambda 25) and optimum extraction condition was obtained with Maximum dye solution absorption of 3.9) at bark powder concentration of $60 \mathrm{~g} / \mathrm{l}$, temperature of $95^{\circ} \mathrm{C}$ and time of $60 \mathrm{~min}$ as shown in Figures 5 and 6.

\begin{tabular}{|c|c|c|c|c|c|c|c|}
\hline Type of mordant & Sample no. & Method & MLR & Conc. (o.w.m) & Temperature & Time & Sample name \\
\hline \multirow{3}{*}{ Copper sulphate } & & PRM & $01: 25$ & $3 \%$ & \multirow{2}{*}{$60^{\circ} \mathrm{C}$} & 60 & CPrm \\
\hline & & POM & & & & $\min$ & CPom \\
\hline & & SM & & & \multicolumn{2}{|c|}{ According to dyeing parameters } & SMC \\
\hline \multirow{12}{*}{ Aloe Vera } & 1 & \multirow{4}{*}{ PRM } & \multirow{4}{*}{-} & $10 \mathrm{~g} / \mathrm{l}$ & \multirow{4}{*}{$70^{\circ} \mathrm{C}$} & \multirow{4}{*}{$60 \mathrm{~min}$} & APrm1 \\
\hline & 2 & & & $20 \mathrm{~g} / \mathrm{l}$ & & & Aprm2 \\
\hline & 3 & & & $30 \mathrm{~g} / \mathrm{l}$ & & & Aprm3 \\
\hline & 4 & & & $40 \mathrm{~g} / \mathrm{l}$ & & & Aprm4 \\
\hline & 1 & \multirow{4}{*}{ POM } & \multirow{4}{*}{-} & $10 \mathrm{~g} / \mathrm{l}$ & \multirow{4}{*}{$70^{\circ} \mathrm{C}$} & \multirow{4}{*}{$60 \mathrm{~min}$} & APom1 \\
\hline & 2 & & & $20 \mathrm{~g} / \mathrm{l}$ & & & Apom2 \\
\hline & 3 & & & $30 \mathrm{~g} / \mathrm{l}$ & & & Apom3 \\
\hline & 4 & & & $40 \mathrm{~g} / \mathrm{l}$ & & & Apom4 \\
\hline & 1 & \multirow{4}{*}{$\mathrm{SM}$} & & $10 \mathrm{~g} / \mathrm{l}$ & \multirow{4}{*}{\multicolumn{2}{|c|}{ According to dyeing parameters }} & SMA1 \\
\hline & 2 & & & $20 \mathrm{~g} / \mathrm{l}$ & & & SMA2 \\
\hline & 3 & & & $30 \mathrm{~g} / \mathrm{l}$ & & & SMA3 \\
\hline & 4 & & & $40 \mathrm{~g} / \mathrm{l}$ & & & SMA4 \\
\hline
\end{tabular}

Table 1: Designed mordanting methods using different parameters

\begin{tabular}{|c|c|c|c|c|c|}
\hline Dyeing conditions & $\mathrm{pH}$ & Temperature $\left({ }^{\circ} \mathrm{C}\right)$ & Time & $\begin{array}{l}\text { Input sample } \\
\text { code }\end{array}$ & Output sample code \\
\hline \multirow{4}{*}{ Dyeing without mordant } & 5.5 & 25 & 20 & \multirow{4}{*}{ Degummed silk fabric } & Dwm1 \\
\hline & 5 & 40 & 30 & & Dwm2 \\
\hline & 4.5 & 55 & 45 & & Dwm3 \\
\hline & 4 & 70 & 60 & & Dwm4 \\
\hline \multirow{4}{*}{ Pre-Mordanting with Aloe Vera } & 5.5 & 25 & 20 & \multirow{4}{*}{ Aprm } & DAPrm1 \\
\hline & 5 & 40 & 30 & & DAPrm2 \\
\hline & 4.5 & 55 & 45 & & DAPrm3 \\
\hline & 4 & 70 & 60 & & DAPrm4 \\
\hline \multirow{4}{*}{ Post-Mordanting with Aloe Vera } & 5.5 & 25 & 20 & \multirow{4}{*}{ APom } & DAPom1 \\
\hline & 5 & 40 & 30 & & DAPom2 \\
\hline & 4.5 & 55 & 45 & & DAPom3 \\
\hline & 4 & 70 & 60 & & DAPom4 \\
\hline \multirow{4}{*}{ Simultaneous mordanting with Aloe Vera } & 5.5 & 25 & 20 & \multirow{4}{*}{ Bleached silk fabric } & SMA1 \\
\hline & 5 & 40 & 30 & & SMA2 \\
\hline & 4.5 & 55 & 45 & & SMA3 \\
\hline & 4 & 70 & 60 & & SMA4 \\
\hline Pre-Mordanting with copper sulphate & 3.5 & 60 & 60 & CPrm & DCPrm \\
\hline Post-Mordanting with copper sulphate & 3.5 & 60 & 60 & CPom & DCPom \\
\hline Simultaneous mordanting with copper sulphate & 3.5 & 60 & 60 & $\begin{array}{l}\text { Degummed } \\
\text { silk fabric }\end{array}$ & SMC \\
\hline
\end{tabular}

Table 2: Different combinations of parameters used to dye silk fabric with the extracted natural dye. 


\section{Performance test results of dyed silk fabric specimens}

Color strength (K/S) value, reflectance (\%) and CIE L ${ }^{*} \mathbf{a}^{*} \mathrm{~b}^{*}$ value: Color developed and color strength on dyed silk fabric samples was evaluated in terms of their CIE $\mathrm{L}^{*} \mathrm{a}^{*} \mathrm{~b}^{*}$ coordinates and $\mathrm{K} / \mathrm{S}$ values. The $\mathrm{L}^{*}$ (lightness/darkens), $\mathrm{a}^{*}$ (redness/greenness), $\mathrm{b}^{*}$ (yellowness/ blueness) value of dyed silk fabric samples obtained from all dyeing and mordanting methods was lied in dark grey to light grey, red and yellow direction respectively. All dyed silk fabric samples are in the red direction which was reflected in $\mathrm{a}^{*}$ and yellow direction in $\mathrm{b}^{*}$ as shown in the CIE L $\mathrm{a}^{*} \mathrm{~b}^{*}$ color space. The value of $\mathrm{b}^{*}$ (yellowness) obtained from dyed samples which are pre mordanted with Aloe Vera was higher than the other dyed samples. The darkness of direct dyed silk fabric samples was higher than the samples mordanted with Aloe Vera clearly shown in Table 3.

In the directly dyed silk fabric samples, the maximum dye absorption (K/S) value and minimum reflectance (\%) was obtained from sample 4 (Dyed silk fabric without mordant 4 ) which was dyed at temperature of $70^{\circ} \mathrm{C}$, time of $60 \mathrm{~min}$ and $\mathrm{pH}$ of 4 as shown in Table 3. This sample was taken as optimum condition for dyeing of silk fabric with the extracted dye.

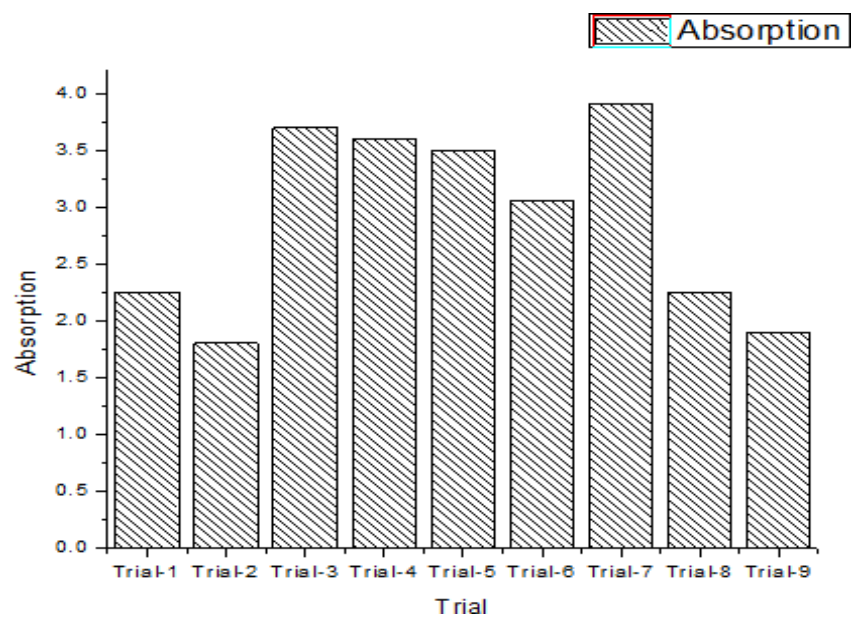

Figure 5: Maximum absorption value of extracted dye solution from each trial at $400 \mathrm{~nm}$.

XXX \% Dye Yield

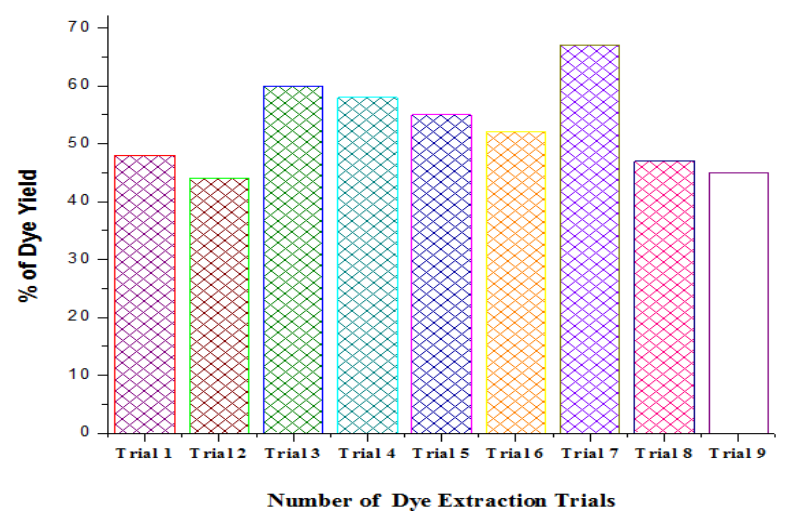

Figure 6: Number of dye extraction trails
In dyed silk fabric which was pre mordanted with Aloe Vera obtained maximum color strength (K/S) 7.01 Sample 4 (Dyed after pre mordanted with Aloe Vera) which is nearly similar result with the simultaneously mordanted with copper sulphate. Silk fabric sample at which simultaneously mordanted with copper sulphate gives highest $\mathrm{K} / \mathrm{S}$ value of 10.42 . The dyed silk fabric samples in which attained maximum $\mathrm{K} / \mathrm{S}$ value has been selected from each group of dyed samples and compared each other. As a result, the sample which was directly dyed sample 4 (DWM4) was attained maximum color strength (K/S) value with 10.50 next to sample which was simultaneously mordanted with copper sulphate as compared with other mordanted samples with Aloe Vera as shown in Figure 5 above.

In general it was observed that, the best $\mathrm{K} / \mathrm{S}$ value was obtained from the samples dyed at temperature $70^{\circ} \mathrm{C}$, time $60 \mathrm{~min}$ and $\mathrm{pH}$ of 4 in all samples which were mordanted with natural extracted mordant from Aloe Vera.

All silk fabric samples were dyed with an extracted natural dye keeping various $\mathrm{pH}$ values as $5.5,5,4.5$, and 4 . It was observed that, the color strength $(\mathrm{K} / \mathrm{S})$ value was good at $\mathrm{pH}$ of 4 as clearly shown in Tables 2 and 3.

Dyebility of silk fabric with the extracted natural dye was evaluated by dying different samples of silk in the presence of Aloe Vera leaf and copper mordants. Maximum K/S (color strength) was got from dyed fabric samples at maximum temperature of $70^{\circ} \mathrm{C}$ and time of 60 min. This is due to the increments of kinetic energy leads to increase diffusion of dye molecules inside the silk at high temperature and increase diffusion rate of dye molecules in to the leather structure at long dyeing time.

Fastness test results: The color fastness (Washing fastness, rubbing fastness and light fastness) properties of dyed silk fabric samples were tested according to the standard ISO methods of ISO 105-CO3, ISO 105-X 12 and ISO 105B02 methods respectively. The performance of Washing fastness, rubbing fastness and light fastness of the dyed silk fabric specimens were presented in Table 4.

In most of the dyed fabric samples, the performance of fastness property was rated within the range of 3-5 except some dyed without mordant and post mordanted samples with Aloe Vera such as DWM1, DWM3 and simultaneous mordanted (Sma1 and Sma2) shows fair (below 3) results. For the light fastness test results, all dyed silk fabric samples showed good to excellent $(6-5$ \& 5,7$)$ except some samples which were directly dyed without mordant and samples which were post mordanted with Aloe Vera showed fair (3-3/4) test results. As the mordant concentration increase the fastness properties of the dyed silk fabric samples also increase in all mordants and mordanting techniques as shown in Table 4.

Samples pretreated with Aloe Vera juice and directly dyed silk fabric samples showed very good to excellent rubbing and washing fastness, and good to very good light fastness property was recorded. Poor rubbing fastness results which is below 3 was obtained from premordanted (Daprm1 and Daprm2), Dapom1 and Dapom2.

In general, natural dye extracted from bark of Cassia singueana plant could be used for commercial purpose in the acceptable color fastness range of international standards for (Washing fatness, Rubbing fastness $>3$ and Light fastness $>5$ ) as shown in Table 4 . 
Citation: Teklemedhin TB, Gopalakrishnan LH (2018) Environmental Friendly Dyeing of Silk Fabric with Natural Dye Extracted from Cassia singueana Plant. J Textile Sci Eng S3: 001. doi:10.4172/2165-8064.S3-001

Page 5 of 6

\begin{tabular}{|c|c|c|c|c|c|c|}
\hline \multirow{2}{*}{ Method } & \multirow{2}{*}{ Sample code } & \multirow{2}{*}{ Reflectance (\%) at $400 \mathrm{~nm}$} & \multirow{2}{*}{$\mathrm{K} / \mathrm{S}$ at $400 \mathrm{~nm}$} & \multicolumn{3}{|c|}{ CIE L* a* b * system } \\
\hline & & & & $\mathrm{L}^{*}$ & $a^{*}$ & $\mathbf{b}^{*}$ \\
\hline \multirow{4}{*}{ Directly dyed without mordant } & DWM 1 & 7 & 3.2 & 52.5 & 22.3 & 25 \\
\hline & DWM2 & 7.4 & 3.2 & 51.25 & 20.8 & 24.5 \\
\hline & DWM 3 & 5.43 & 6.53 & 45.5 & 25.25 & 26.48 \\
\hline & DWM4 & 3.06 & 10.5 & 38.46 & 27.4 & 22.09 \\
\hline \multirow{4}{*}{ PRM with Aloe Vera } & DPRMA 1 & 9.87 & 3.04 & 55.3 & 15.6 & 22.1 \\
\hline & DPRMA 2 & 7.05 & 4.22 & 50.04 & 19.60 & 23.07 \\
\hline & DPRMA3 & 5.40 & 5.01 & 48.32 & 23.02 & 26.26 \\
\hline & DPRMA4 & 6.78 & 7.28 & 49.07 & 25.5 & 28.05 \\
\hline \multirow{4}{*}{ POM with Aloe Vera } & DAPom1 & 11.26 & 2.14 & 57.74 & 13.82 & 20.18 \\
\hline & DPOMA 2 & 6.68 & 4.55 & 52.58 & 19.66 & 23.29 \\
\hline & DPOMA3 & 6.21 & 4.97 & 49.68 & 24.06 & 27.07 \\
\hline & DPOMA 4 & 5.18 & 5.12 & 48.74 & 17.03 & 25.90 \\
\hline \multirow{4}{*}{ SM with Aloe Vera } & SMA1 & 6.82 & 4.43 & 49.96 & 15.40 & 21.86 \\
\hline & SMA2 & 5.60 & 5.61 & 47.72 & 16.58 & 23.18 \\
\hline & SMA3 & 5.56 & 5.65 & 50.92 & 16.81 & 26.20 \\
\hline & SMA4 & 5.10 & 5.83 & 44.26 & 17.92 & 24.72 \\
\hline $\begin{array}{l}\text { PRM with copper } \\
\text { sulphate }\end{array}$ & DCPrm & 3.63 & 8.82 & 36.91 & 10.99 & 16.79 \\
\hline $\begin{array}{l}\text { POM with copper } \\
\text { sulphate }\end{array}$ & DCPom & 3.90 & 8.22 & 39.00 & 16.54 & 21.27 \\
\hline $\begin{array}{l}\text { SM with copper } \\
\text { sulphate }\end{array}$ & SMC & 3.03 & 10.42 & 39.00 & 16.57 & 15.96 \\
\hline
\end{tabular}

Table 3: Color strength $(\mathrm{K} / \mathrm{S})$ value, reflectance $(\%)$ and $\mathrm{CIEL}^{*} \mathrm{a}^{*} \mathrm{~b}^{*}$ values of dyed silk fabric samples with the extracted dye and using different mordants at $10^{\circ} \mathrm{C}$ observer.

\begin{tabular}{|c|c|c|c|c|c|c|c|c|}
\hline \multirow{2}{*}{ Type of mordant } & \multirow{2}{*}{$\begin{array}{l}\text { Method of } \\
\text { mordanting }\end{array}$} & \multirow{2}{*}{ Sample code } & \multirow{2}{*}{$\begin{array}{c}\text { Mordant } \\
\text { concentration }\end{array}$} & \multicolumn{2}{|c|}{ Rubbing fastness } & \multirow{2}{*}{$\begin{array}{c}\text { Light fastness } \\
24 \mathrm{hr}\end{array}$} & \multicolumn{2}{|c|}{ Wash fastness } \\
\hline & & & & Dry & Wet & & Acidic & Basic \\
\hline \multirow{4}{*}{ Nil } & \multirow{4}{*}{$\begin{array}{l}\text { Dyed without } \\
\text { mordant }\end{array}$} & Dwm1 & Nil & $3 / 4$ & 3 & $4-5$ & 3 & 3 \\
\hline & & Dwm2 & Nil & 4 & 3 & 5 & 3 & $3 / 4$ \\
\hline & & Dwm3 & $\mathrm{Nil}$ & $3 / 4$ & $3 / 4$ & 5 & $3 / 4$ & 4 \\
\hline & & Dwm4 & Nil & 5 & 4 & 6 & 4 & 5 \\
\hline \multirow{12}{*}{ Aloe Vera juice } & \multirow{4}{*}{ PRM } & DAPrm1 & $10 \mathrm{~g} / \mathrm{l}$ & 3 & 2 & 5 & 3 & $3 / 4$ \\
\hline & & DAPrm2 & $20 \mathrm{~g} / \mathrm{l}$ & 4 & 2 & $5-6$ & $3 / 4$ & 3 \\
\hline & & DAPrm3 & $30 \mathrm{~g} / \mathrm{l}$ & $4 / 5$ & 4 & $5-6$ & 4 & $4 / 5$ \\
\hline & & DAPrm4 & $40 \mathrm{~g} / \mathrm{l}$ & 5 & $4 / 5$ & 6 & $4 / 5$ & 5 \\
\hline & \multirow{4}{*}{ POM } & DAPom1 & $10 \mathrm{~g} / \mathrm{l}$ & 3 & $2 / 3$ & 5 & 3 & 4 \\
\hline & & DAPom2 & $20 \mathrm{~g} / \mathrm{l}$ & 3 & $2 / 3$ & 4 & $3 / 4$ & $3 / 4$ \\
\hline & & DAPom3 & $30 \mathrm{~g} / \mathrm{l}$ & 4 & 4 & $5-6$ & $3 / 4$ & $3 / 4$ \\
\hline & & DAPom4 & $40 \mathrm{~g} / \mathrm{l}$ & $4 / 5$ & 4 & 6 & 4 & $4 / 5$ \\
\hline & \multirow{4}{*}{ SM } & SMA1 & $10 \mathrm{~g} / \mathrm{l}$ & $4 / 5$ & $2 / 3$ & 5 & 3 & 3 \\
\hline & & SMA2 & $20 \mathrm{~g} / \mathrm{l}$ & 4 & 3 & $5-6$ & 4 & 3 \\
\hline & & SMA3 & $30 \mathrm{~g} / \mathrm{l}$ & 4 & 4 & 6 & 4 & $3 / 4$ \\
\hline & & SMA4 & $40 \mathrm{~g} / \mathrm{l}$ & $4 / 5$ & 2 & 6 & $4 / 5$ & $4 / 5$ \\
\hline \multirow{3}{*}{ Copper sulphate } & PRM & DCPrm & $3 \%$ (o.w.m) & $4 / 5$ & 5 & $6-7$ & 4 & $4 / 5$ \\
\hline & POM & DCPom & $3 \%$ (o.w.m) & 5 & $4 / 5$ & 7 & $4 / 5$ & 5 \\
\hline & SM & SMC & $3 \%$ (o.w.m) & 5 & 5 & 8 & $4 / 5$ & 5 \\
\hline
\end{tabular}

Table 4: Color fastness properties test result of dyed leather samples with bark extract and different mordants.

\section{Conclusion}

The present work shows that, barks of Cassia singueana plant can be used as a dye for coloring of silk fabric in the presence of natural mordant extracted from Aloe Vera. Cassia singueana plant is grown throughout Ethiopia, Nigeria, Egypt and some areas of India and it is an easily available plant makes the raw material cheap. As some authors studied the chemical composition of this plant, it has antimicrobial and anti-mosquito property in addition to use as natural colorant. This plant extract for coloration of silk fabric would give the benefits of reducing import of synthetic dyes and minimize environmental pollution. The washing, light and rubbing fastness of all dyed silk fabrics without and using natural mordant were quite good. The dye has good scope in the commercial dyeing of Protein fibers.

\section{References}

1. Sudha M, Saranya A, Selvakumar G, Sivakumar N (2014) Microbial degradation of azo dyes: a review. Int J Curr Microbiol Appl Sci 3: 670-690.

2. Pervaiz S, Mughal TA, Khan ZF, Najeebullah M (2016) Extraction of natural dye from Rosa damascena Miller: A Cost effective approach for leather industry. Inter Network for Natural Sci 8: 83-92.

3. Devi VNM, Ariharan VN, Prasad PN (2013) Annato: eco-friendly and potential source for natural dye. Int Res J Pharm 4: 106-108. 
Citation: Teklemedhin TB, Gopalakrishnan LH (2018) Environmental Friendly Dyeing of Silk Fabric with Natural Dye Extracted from Cassia singueana Plant. J Textile Sci Eng S3: 001. doi:10.4172/2165-8064.S3-001

4. Dan'Azumi S, Bichi M (2010) Industrial Pollution and Heavy Metals Profile of Challawa River in Kano, Nigeria. J Appl Sci Environ Sanit 5: 56-62.

5. Kamel MM, El-Shishtawy RM, Yussef BM, Mashaly H (2005) Ultrasonic assisted dyeing: III. Dyeing of wool with lac as a natural dye. Dyes Pigm 65: 103-110.

6. Samanta KA, Agarwal P (2009) Application of natural dyes on textiles. Indian J Fibre Text 34: 384-399.

7. Bhuyan R, Saikia C (2004) Extraction and identification of colour components from the barks of Mimusops elengi and Terminalia arjuna and evaluation of their dyeing characteristics on wool. Indian J Fibre Text 29: 470-476.

8. Adeel S, Ali S, Bhatti AI, Zsila F (2009) Dyeing of cotton fabric using pomegranate (Punica granatum) aqueous extract. Asian J Chem 21: 3493-3499.

9. Purohit A, Mallick S, Nayak A, Das BN, Nanda B, et al. (2007) Developing multiple natural dyes from flower parts of Gulmohur. Current Science Assoc Indian Academy of Sciences 92: 1681-1682.

10. Adem O (1996) Extraction of dyestuff from onion (Allium cepa L.) and its application in the dyeing of wool, feathered-leather and cotton. Turk $\mathrm{J}$ Chem 20: 194-203.

11. Kulkarni SS, Gokhale AV, Bodake UM, Pathade GR (2011) Cotton Dyeing with Natural Dye Extracted from Pomegranate (Punica granatum) Peel. Univers J Environ Res Technol 1: 135:139.

12. Saravanan P, Chandramohan G, Mariajancyrani J, Kiruthikajothi K (2014) Ecofriendly dyeing of wool fabric with a natural dye extracted from barks of Odina wodier. Der Chemica Sinica 5: 28-33.

13. Gulrajani M (1992) Introduction to Natural Dyes, Indian Institute of Technology. New Delhi: India.

14. Acquah SB, Oduro K (2012) Traditional cloth dyeing enterprise at Ntonso: Challenges and opportunities. West African J Applied Ecology 20: 25-36.

15. Rungruangkitkrai N, Mongkholrattanasit R (2012) Eco-Friendly of textiles dyeing and printing with natural dyes. RMUTP International Conference: Textiles \& Fashion.
16. Endo M, Naoki H (1980)Antimicrobial and antispasmodic tetrahydroanthracenes from Cassia singueana. Tetrahedron 36: 2449-2452.

17. Adzu B, Abbah J, Vongtau H, Gamaniel K (2003) Studies on the use of Cassia singueana in malaria ethnopharmacy. J Ethnopharmacol 88: 261-267.

18. Mutasa S, Khan MR, Jewers K (1990) 7-Methylphyscion and Cassiamin A from the Root Bark of Cassia singueana. Planta Medica 56: 244-245.

19. Berhanu T, Ratnapandian S (2017) Extraction and Optimization of Natural Dye from Hambo Hambo (Cassia singueana) Plant Used for Coloration of Tanned Leather Materials. Adv Mater Sci Eng.

20. Nilani P, Duraisamy B, Dhamodaran P, Kasthuribai N, Semwo A (2008) A study on the effect of marigold flower Dye with natural mordant on selected Fibers. $J$ Pharm Res 1: 175-181.

21. Athiban PP, Borthakur BJ, S Ganesan, B Swathika (2012) Evaluation of antimicrobial efficacy of Aloe vera and its effectiveness in decontaminating gutta percha cones. J Conserv Dent 15: 246-248.

22. Pervaiz S, Aziz M, Khan ZF, Najeebullah M (2016) Floral Dyes: An Opportunity for Punjab Leather Industry to Promote Sustainable Fashion Development. Inter J Res in Advent Tech 4: 34-39.

23. Win ZM, Swe MM (2008) Purification of the natural dyestuff extracted from Mango bark for the application on protein fibers. World Acad Sci Eng Technol 22: $536-540$.

24. Cardon D, Higgitt C (2007) Natural dyes. Sources, tradition, technology and science. London: Archetype Publications, cop.

25. Shoba K, Singh P, Nainwal P, Kumari K (2016) Dyeing Effect of Colour Obtain From Bark of Morus Alba on Selected Fibers. Inter J Pharma and Chem Res 2. $164-166$.

26. Srivastavaa S, Chopraa A (2015) Agro fertigational response of sugar mill effluent and synthetic fertilizer (DAP) on the agronomy of crop Vigna unguiculata L. Walp in two seasons. Res J Agricl Environ Sci 2: 5-17.

27. Sangeetha K, Bhuvaneshwari M, Gomathi R (2015) Dyeing of Silk Fabric using Lemon Leaves Extract with the Effect of Different Mordants. Inter J Innovative Res in Sci, Eng Tech 4: 4692-4697. 